\title{
Strategic Environmental Assessment (SEA) Analysis for the Municipal Development Plan (MDP) of Ferizaj Municipality
}

\author{
${ }^{1}$ Sylejman Berisha, ${ }^{2}$ Ismajl Baftjari, ${ }^{2}$ Alban Sokoli and ${ }^{2}$ Elon Berisha \\ ${ }^{1}$ Faculty of Education, University of Prishtina, Prishtina, Republic of Kosova \\ ${ }^{2}$ Institute of Science and Tehnology, INSI shpk, Prishtina, Republic of Kosova
}

\begin{abstract}
Strategic Environmental Assessment (SEA) is one of the key instruments for integrating environmental issues, principles of sustainable development, proposed programs and decision-making during drafting of the Municipal Development Plan (MDP). The purpose of this research is to analyze and observe in details, the Strategic Environmental Assessment Report (SEA) for the Municipal Development Plan of the Municipality of Ferizaj. The elements of the Strategic Environmental Assessment Report (SEA) are reviewed and analyzed in this study starting from: the national and EU legal basis for drafting this document, the analysis of the existing situation of environmental factors in Ferizaj Municipality (geographic position, population, drinking water supply, contaminated water treatment, etc.), the analysis of the development concept of the Municipality of Ferizaj and the priorities of the scenarios given for the municipal development plan, the goals and objectives of the Municipal Development Plan (MDP) and their harmonization with national legal frameworks, the testing of the goals of municipal development plan. The Strategic Environmental Assessment (SEA) objectives are: water supply, sewage management, traffic and integrated waste management and the necessary SEA measures for the Municipal Development Plan (MDP). The environmental solutions proposed by $\mathrm{MDP}$ are accurate and conform to the current solutions for environmental problems in EU countries. Scenarios 3 and 4 proposed by Municipal Development Plan (MDP) for environmental development of the Ferizaj Municipality are accurate and realistic. The research concludes that the main challenge is the practical implementation of the Municipal Development Plan (MDP) targets such as: the conservation of biodiversity and natural habitats, the implementation of district heating and wastewater treatment in the Municipality of Ferizaj, the definition of ecological corridors during the realization of planned projects, the designing of rehabilitation projects for depleted uranium irradiation areas. Therefore, the implementation of the MDP and the implementation of SEA recommendations are a challenge for the management of the Ferizaj Municipality.
\end{abstract}

Key words: Strategic environmental assessment (VSM), Municipal Development Plan (MDP), objective environmental, Ferizaj Municipality, environmental development, implementation

\section{INTRODUCTION}

The Strategic Environmental Assessment Report for the Municipal Development Plan of the Municipality of Ferizaj is a legal obligation. The strategic environmental assessment is a process aimed at integrating environmental issues into the preparation and adoption of plans, programs and policies. The purpose of the Strategic Environmental Assessment (SEA) Report for the Municipal Development Plan of Ferizaj is to identify, describe and evaluate the impacts that may result from the implementation of the MDP as well as to provide the most favorable options for its development from the environmental point of view. Also, the SEA Report should include measures proposed for avoiding harmful impacts arising from the proposals of the Municipal Development Plan.

The methodology followed is in accordance with the EU Directive 2001/42/EC on the 'Evaluation of the Effects of Certain Plans and Programs on the Environment' and the Law on 'Environmental Impact Assessment'.

Based on this directive, the SEA should include at least some of the following points: a summary of basic informations on environmental assessment, the priorities and main objectives of the Municipal Development Plan of Ferizaj, the description of existing environmental problems that are relevant to the plan and the ways in which the objectives have been taken into account when

Corresponding Author: Alban Sokoli,Institute of Science and Tehnology, INSI shpk, Prishtina, Republic of Kosova 
preparing the SEA Report. Strategic Environmental Assessment (SEA) is the key instrument for integrating environmental issues and sustainable development principles into strategic planning and decision-making. It is an instrument which provides guidance for the sustainable management of the MDP's environmental aspects. SEA provides guidance on the inclusion of environmental issues in projects that will be realized in the future.

\section{LEGAL AND INSTITUTIONAL FRAMEWORK OF SEA}

When drafting the SEA, many documents need to be considered such as: EU Directive 2001/42/EC on Strategic Environmental Assessment (27.06.2001). The directive applies to a wide range of public plans and programs (e.g., land use, transport, energy, waste, agriculture, etc.)

EU 2020 Strategy for Strategic Environmental Assessment is an important policy document for both the EU and the neighboring regions in particular the Western Balkans. The strategy's main priority is rapid, sustainable, inclusive growth. The strategy also includes the objectives that need to be achieved such as: $20 \%$ reduction in greenhouse gas emissions and an increase in energy efficiency to $20 \%$ from renewable energy sources (Anonymous, 2017).

Arhus Convention (Convention on Access to Information, Public Participation in Decision-making and Access to Justice in Environmental Matters) which was approved on 25 June 1998 in the City of Arhus at the Fourth Conference as part of the "Environment for Europe" process (Fourth Ministerial Conference in (Aarhus, June 1998).

Kosovo Law on Spatial Planning, Law on Spatial Planning, Law No. 03/L-106), (Law No.03/L-106 amending law on Spatial Planning No. 2003/14) while in July 2013 the new Law on Planning (Law No. 04/L-174) was approved. According to Law No. 04/L-174 there are 2 levels of planning in Kosovo, Central and Local and the types of plans are: Kosovo Spatial Plan, Kosovo Zonal Map, Spatial Plans for Special Areas, Municipal Development Plans (MDPs), Commune Zones Map and Detailed Urban Regulatory Plans (Anonymous, 2011, 2013).

Kosovo's Law on Strategic Environmental Assessment (SEA)-Law No. 03/L-230 underlines the importance of integrating environmental protection principles during the preparation, approval and implementation of the respective plans and programs.

Current environmental situation: The data below refer to the current environmental situation in the Municipality of
Ferizaj. The main purpose of the data discussion is to identify the environmental situation and to deal with the vision, priorities and desired effects of the development and implementation of the Municipal Development Plan of the Municipality of Ferizaj. The environmental condition in the Municipality of Ferizaj is characterized by the description of the environmental receptors as required by the SEA directive which are described as it follows: population and public health, zoodiversity, nature protected areas, air quality, noise and unpleasant sights, climatic factors, climate change, water, agricultural land and landscape, material assets/physical infrastructure (transport and waste management) and cultural heritage. Several impacts that are related to the health of the population are identified as:

Construction/rehabilitation of sewerage, sewage treatment and waste management

Rehabilitation of high pollution areas and those with potential for pollution

Preservation of fresh water resources from pollution and increased water demand with intensive infrastructure growth in high density residences

Promotion of mobility, walking and cycling and redesigning public traffic to reduce the emissions of gases and noises in the city

The quality of buildings, density and zoning should be adequately supported by other municipal services Construction reports: green areas and population density forecasts

Geographic position: Ferizaj is located in the South of the central part of Kosovo. The Municipality of Ferizaj represents an important crossroad because along this city pass all the important roads that cross Kosovo. (Table 1).

Municipality of Ferizaj has an area of $344.64 \mathrm{~km}$. There are 44 villages in which half of the population of this municipality live. The largest villages are Dardania, Gremja, Komogllava where there are over 6,000 residents (Fig. 1-6).

The territory of Ferizaj/Urosevac municipality is located at an latitude of over $500 \mathrm{~m}$ or $43.0 \%$ of the surface areas are located up to $600 \mathrm{~m}$ above sea level which are more suitable for plant production. The geological construction of Ferizaj is mainly composed of: serpentine, sandstone, marlstone, mudstone, siltstone, limestone, conglomerate (Steiner and Butler, 2012).

Table 1: Spatial characteristics of the municipality

\begin{tabular}{lccl}
\hline Area $\left(\mathrm{km}^{2}\right)$ & Population & Density $\left(\mathrm{ba} / \mathrm{km}^{2}\right)$ & $\begin{array}{l}\text { Average altitude } \\
\text { above sea level }\end{array}$ \\
\hline $\mathbf{3 4 4 . 6 4}$ & 10810 & 315.14 & $500 \mathrm{~m}$ \\
\hline
\end{tabular}




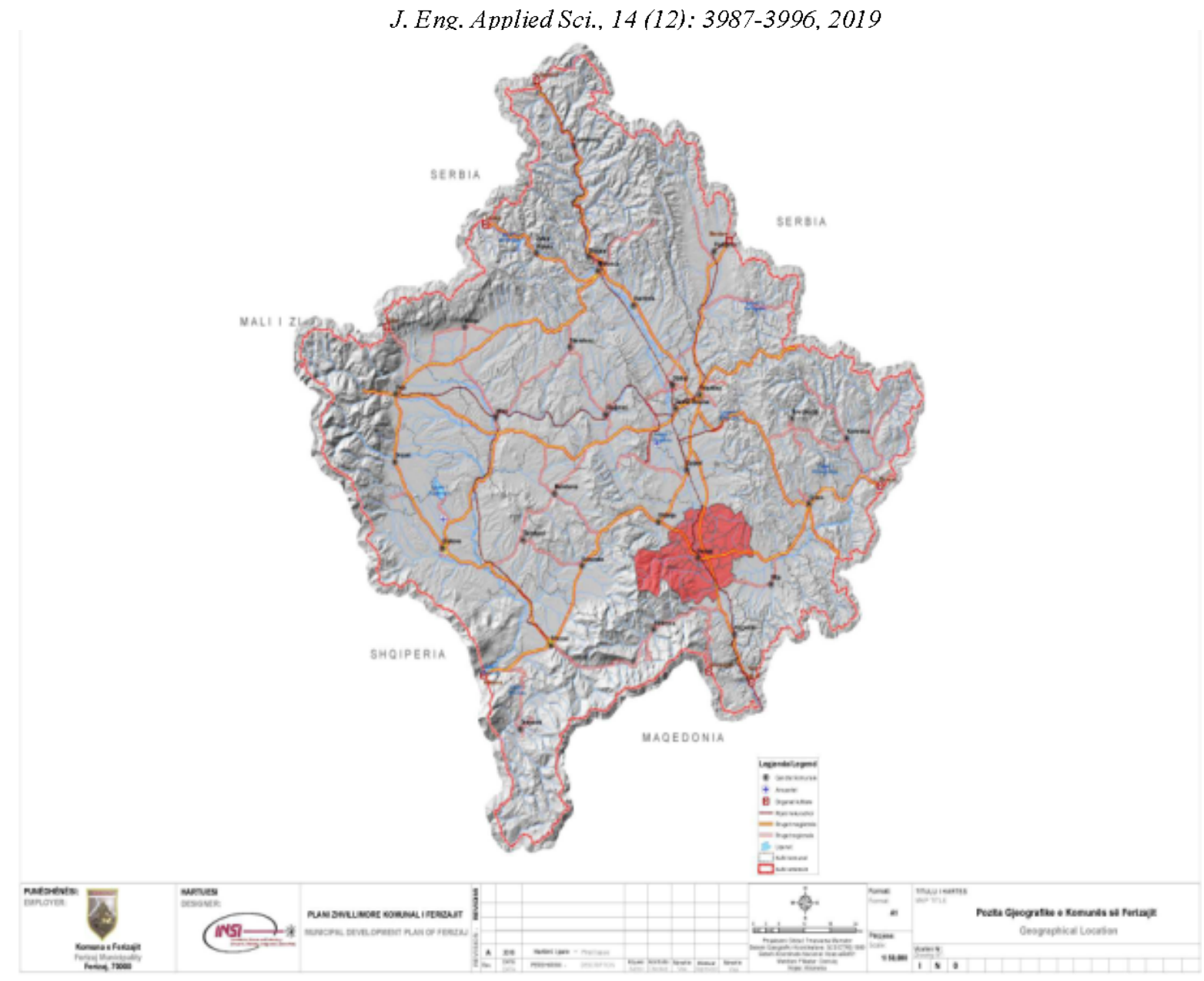

Fig. 1: Geographic position of the Municipality of Ferizaj

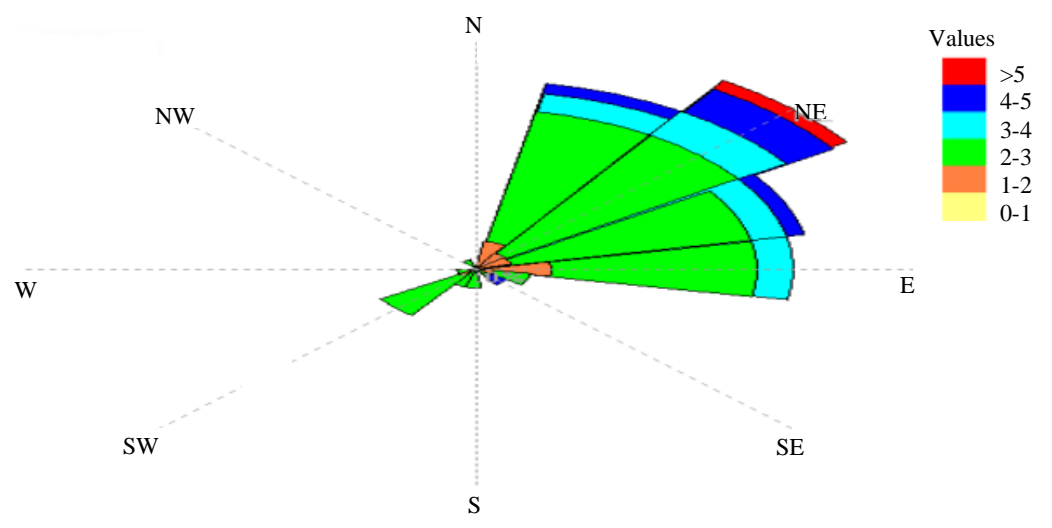

Fig. 2: Pink in the Municipality of Ferizaj

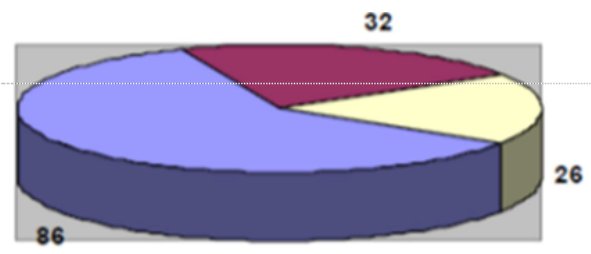

86 - The number of intemationally important species

32 - Number of species included in the IUCN list

26 - Number of species included in the European Red List

Fig. 3: The floristic plant spectrum of Sharri Mountains with international protected status 
J. Eng. Applied Sci., 14 (12): 3987-3996, 2019

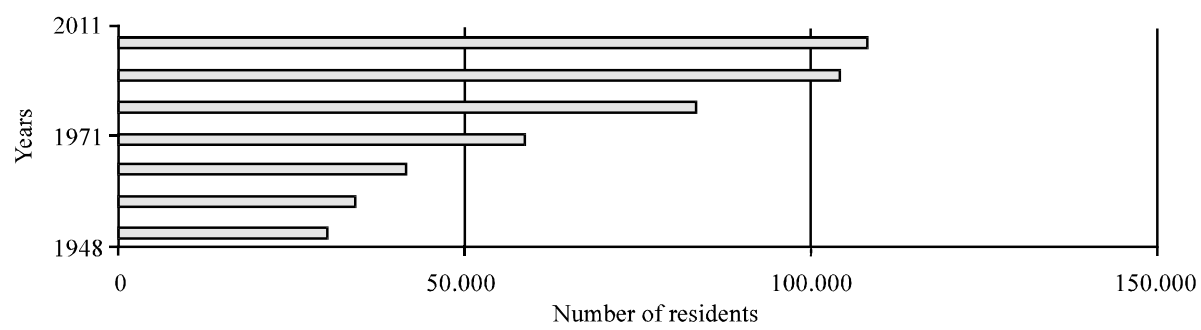

Fig. 4: The number of residents of Ferizaj Municipality during the period 1948-2011 (Residents of the Municipality)
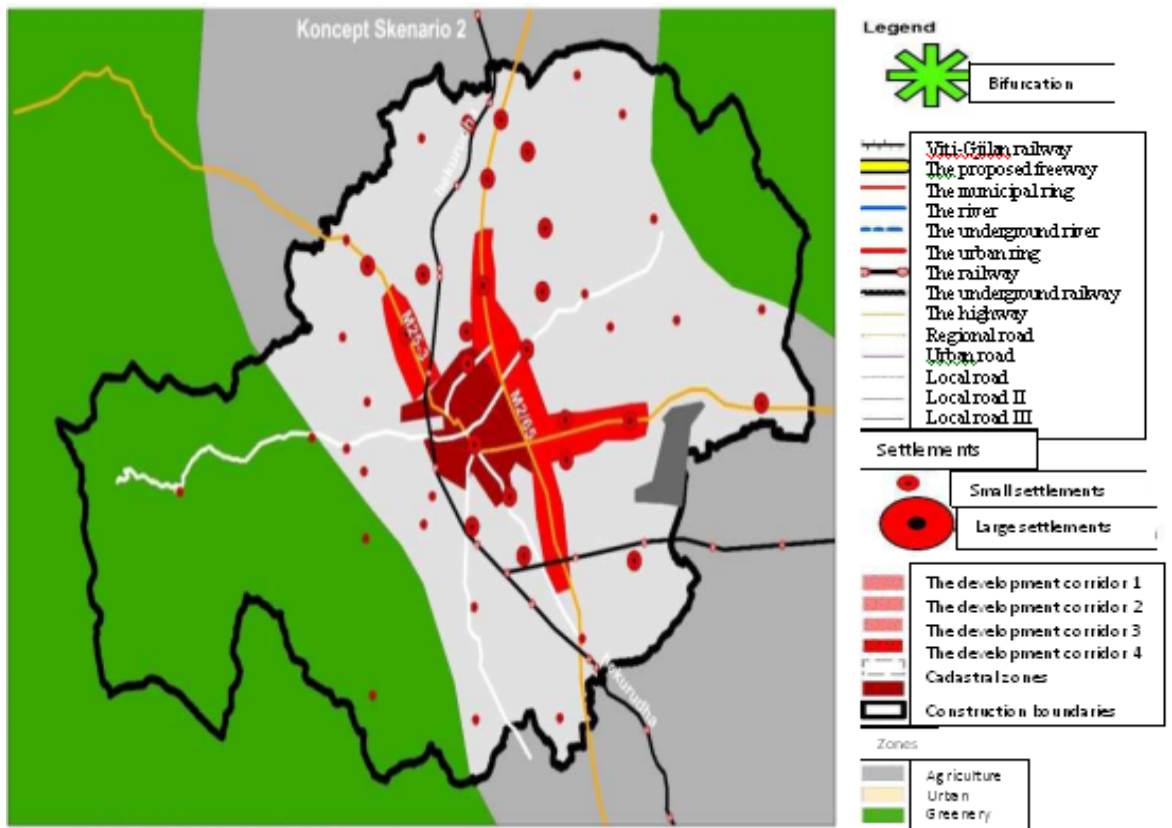

Fig. 5: Spatial development municipality according to scenario 3 and keys
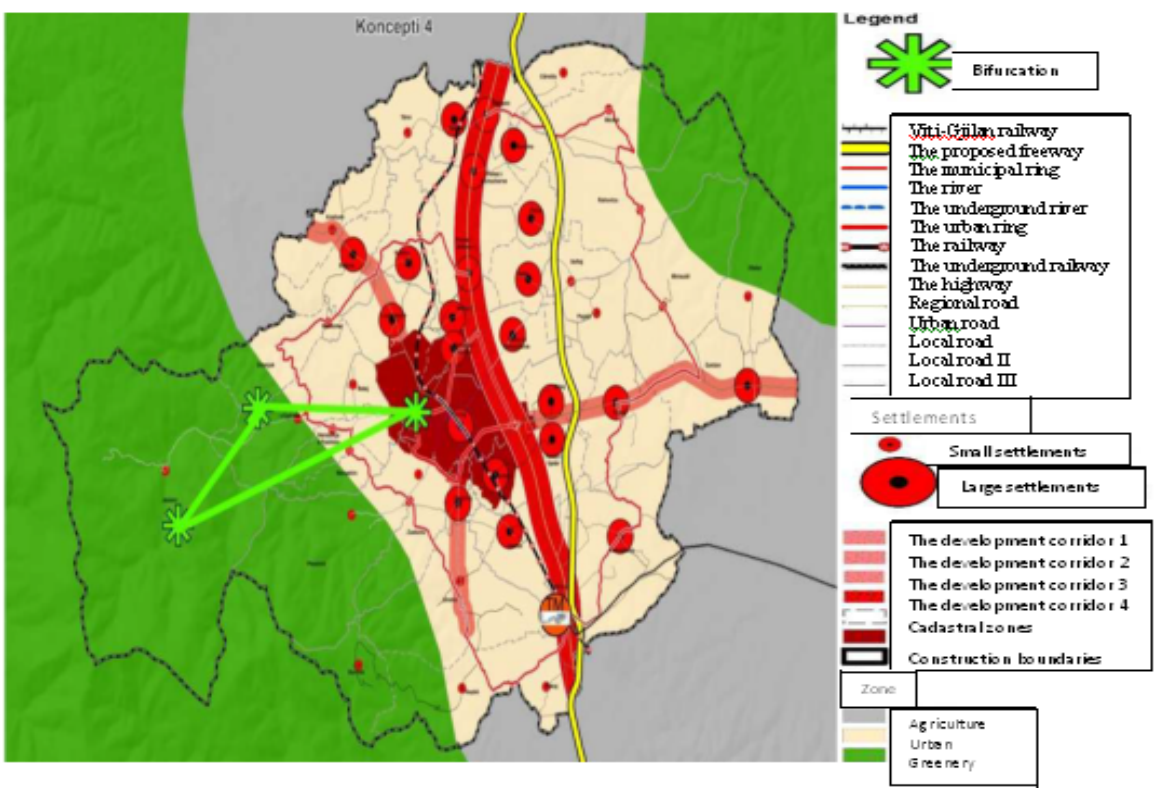

Fig. 6: Spatial development municipality according to scenario 4 and keys 
Flora and fauna: The biogeography of the Ferizaj Municipality depending on the geographical environment can be divided into: Phyto-Geography and Zoogeography. In this region, we can encounter: Quercus cerris, Fagus moesiacae, Alnetum glutinosae, then the phytocenosis of algae, mycoses, lichens, fibres. Phytocenosis of herbaceous plants with medicinal and nutritional value (Coryletum avellanae). The forests from the Sharri Mountains provide conditions for livelihoods of large mammals such as the brown bear (Ursus arktus), Capreolus, Wild goat (Rupicapra rupicapra), then many species of birds, very important for the Ornito fauna of Kosovo and beyond such as: The Eagle of the Mountains (Aquila chrysaetos) and some representative species of the country which have national and international protected status.

The population of Ferizaj Municipality: Population database in Kosovo as a whole as well as on the population of the city of Ferizaj Municipality is relatively uncertain. The last general registration of the population in Kosovo was in 1991, meanwhile, the most reliable dates back to 1981 and 1971.

The bifurcation phenomenon in the city of Ferizaj: As far as natural heritage is concerned Ferizaj is not, so rich but what makes it famous is undoubtedly the water spout that is the only one in Europe and the phenomenon of bifurcation. Similar to this natural phenomenon (bifurcation) it is said to be one in the State of Colorado of the United States of America. In 2012, the European Commission operating in Kosovo has made the arrangement of the river bed and has made the sidewalk adjustment for visitors.

Infrastructure, electricity, water supply and sewerage: The electrical network is extended to all the residencies of the municipality. The $400 \mathrm{kV}$ station in Sojeve represents a good opportunity for sustainable supply of electricity for the municipality. Huge power losses are due to very long outputs and outdated equipment. The city of Ferizaj is supplied with water from four rivers. The accumulated water goes to the water treatment plant in Pleshine which has a reservoir of $\mathrm{V}=5000 \mathrm{~m}^{3}$, from where the villages of Nekodime, Doganaj, Dubrava, Pleshine e Ulet, Zaskok, Talinoc i Jerlive and Blenisht are supplied with water.

Water resources capacities, according to the company Kruk "Bifurkacioni" are: Lumi i Madh-Jezerc (80-100) 1/s. Lumi i Vogel-Nerodime (45-70) 1/s. . Prroji i Syles-Pleshine (20-45) 1/s, Prroji i Pukes-Pleshine (10-25) $(1 / \mathrm{s})$. The maximum cleaning capacity of this plant is 200-250 (1/s).
Table 2: The extent of the existing network

\begin{tabular}{lccc}
\hline & Urban area & & \\
& ------------------- & \\
Variables & Downtown area & East side & Total \\
\hline Network (meter length) & 70285 & 46700 & 116985 \\
Wells (Number) & 2144 & 1305 & 3449 \\
\hline
\end{tabular}

Ferizaj is a city surrounded by many villages. Almost the entire city and the villages have a sewerage system where all the wastewaters are discharged into the Neredime River. The number of these discharge points reaches 22 . The following table shows the extent of the existing network (Table 2).

\section{SEA OBJECTIVES FOR THE MUNICIPAL DEVELOPMENT PLAN OF FERIZAJ}

The environmental objectives of SEA, that are in agreement with the environmental protection goals of Ferizaj Municipal Development Plan have been defined. These objectives are built in accordance with the national environmental policy strategies, the Kosovo spatial plan, and the positions of relevant sectors (affected by the objectives). The main objectives associated with this plan can be defined as.

Environmental objective 1; Air: Fulfillment of mediumterm objectives for the annual emissions of pollutants, according to the maximum limits allowed by the European Union.

Environmental objective 2; Water: Preventing the negative effects of human activity on surface and groundwater resources including drinking water.

Environmental objective 3; Land: Protection, use and management of the land and natural resources.

Environmental objective 4; Biodiversity: Protection and management of biodiversity in function of ecosystem's conservation.

Environmental objective 5; Forests: Sustainable forest management, in order to guarantee the ecosystem resilience skills.

Environmental objective 6; Landscape and ecosystems: Landscape management as a basis for ensuring sustainability for ecosystem services.

Environmental objective 7; Climate change: Adopting appropriate measures and infrastructure to maintain climate change and the greenhouse effect. 
Environmental objective 8; Cultural heritage: Preservation and restoration of historical objects and areas of cultural and archaeological heritage.

Environmental objective 9; Quality of life: Ensuring social, economic, environmentally friendly development.

Development scenarios, according to the MDP of the Municipality of Ferizaj: The concept of Spatial Development has been analyzed and addressed through scenarios and maps that describe: the city's expansion and development, future land use requirements, protection measures for particular areas, etc. The scenarios 3 and 4 are presented in this research only because the scenarios 1 and 2 have not been further developed due to the lack of data during the analysis of the MDP (Anonymous, 2008).

Scenario 3: "Ferizaj as a polycentric municipality with the railroad that passes through the center" shows that:

. The development is concentrated in the city of Ferizaj and in some residences

- Plains of the municipality are used for agriculture

- A ring road is built outside Ferizaj, removing the traffic from the city

- A corridor of economic development has been built in Gerlice, Ferizaj and Babush

Advantages of this scenario: The concentrated development makes it possible to effectively exploit the land, large parts of the plains can be used for agriculture, short distances within the city, long-distance traffic is held outside the city of Ferizaj and the railway station in the city center.

The disadvantages of this scenario: There is no development in the villages in the suburbs, development of large areas creates the risk of urban stretching incorrect and ineffective use of the ring road only on one side and railways are creating a barrier through the city. Scenario 3 will be developed in combination with other municipal action plans.

Scenario: "Ferizaj as a polycentric municipality with an underground passage in the center of the city" shows that: development is distributed in the city and in some secondary centers, plain parts are used for agriculture, the ring road is created with the combination of the existing road and the new road, new constructions have been developed on both sides of the ring road and there are functional links to tourist areas.

\section{Advantages of this scenario:}

The concentrated development makes it possible to effectively exploit the land
Both the city and the majority of the villages are provided with the necessary services

Large parts of the plain can be used for agriculture

Short distances within the city

Long-distance traffic is held outside the city of Ferizaj

The modern railway station in the city center

The disadvantages of this scenario: Far away villages have no development. Scenario 4 will be developed in combination with action plans.

Testing the MDP goals with SEA objectives: The Strategic Environmental Assessment (SEA) has proven to be effective in supporting the planning process and identifying specific environmental issues. The SEA objectives have been identified by considering the environmental and sustainable development objectives set out in relevant laws and strategic actions. In the municipal development plan are set 46 goals, bat in this study are presented only 24 of them as follows (Table 3-5):

Goals of the Municipal Development Plan of Feriza:

Goal 1; Extinction of extreme poverty and hunger

Goal 2; To achieve primary universal education for all

Goal 3; Supporting gender equality and empowering women

Goal 4; Decrease the child mortality

Goal 5; Improvement of maternal health

Goal 6; Combating HIV/AIDS, malaria and other epidemic diseases

Gool 7; Ensuring environmental sustainability

Goal 8; Building a Global Partnership for development

Goal 9; Sustainable economic development in all areas

Goal 10; Creating a sustainable system of development of agriculture and rural development, quality and modern infrastructure in the Municipality of Ferizaj

Goal 11; Creating conditions for utilizing tourism potentials and natural areas for the development of tourism in the area of the Jezerc Mountains, Burrnik Mountains as well as bifurcation in the Neredime River

Goal 12; Quality and sustainable supply of drinking water for all residents of the Municipality Goal 13; Elimination of environmental pollution from sewage

Goal 14; Modernization and expansion of wastewater treatment infrastructure

Goal 15; Separation of sewage from atmospheric waters 
Table 3: Compliance of municipal development plan goals with SEA objectives; Clarification: + Compliance at a considerable level; +Satisfactory compatibility; 0 No effect; -A small possible conflict; -/-Significant possible conflict; +/Compatibility and conflict elements

\begin{tabular}{|c|c|c|c|c|c|c|c|c|c|c|c|}
\hline \multirow[b]{2}{*}{ SEA objectives } & \multicolumn{11}{|c|}{ The goals of MDP of Ferizai } \\
\hline & Goal 1 & Goal 2 & Goal 3 & Goal 4 & Goal 5 & Goal 6 & Goal 7 & Goal 8 & Goal 9 & Goal 10 & Goal 11 \\
\hline $\begin{array}{l}\text { Air: Reducing Greenhouse } \\
\text { Gas Emissions }\end{array}$ & 0 & 0 & 0 & + & + & 0 & + & + & - & - & 0 \\
\hline Water quality increase & 0 & 0 & 0 & + & + & 0 & + & + & - & $-1+$ & 0 \\
\hline $\begin{array}{l}\text { Land protection and } \\
\text { management }\end{array}$ & 0 & 0 & 0 & 0 & 0 & 0 & + & $-i+$ & $-1+$ & $\mathrm{u}$ & u \\
\hline $\begin{array}{l}\text { Biodiversity: } \\
\text { Protection and } \\
\text { management }\end{array}$ & 0 & 0 & 0 & 0 & 0 & 0 & + & $-i+$ & + & 0 & $+i-$ \\
\hline $\begin{array}{l}\text { Forests: Sustainable forest } \\
\text { management }\end{array}$ & 0 & + & 0 & 0 & 0 & 0 & + & + & $-1+$ & u & $-1+$ \\
\hline $\begin{array}{l}\text { Landscpe nd } \\
\text { ecosistem. }\end{array}$ & 0 & 0 & 0 & 0 & 0 & 0 & + & $-i+$ & - & $-1+$ & 0 \\
\hline Climate change & 0 & 0 & 0 & & 0 & 0 & + & - & - & 0 & 0 \\
\hline Cultural heritage & 0 & 0 & 0 & 0 & 0 & 0 & 0 & + & + & 0 & 0 \\
\hline Quality of life & + & + & 0 & + & + & + & 0 & + & + & + & + \\
\hline
\end{tabular}

Table 4: Compliance of municipal development plan goals with SEA objectives; Clarification: ++Compliance at a considerable level; +Satisfactory compatibility; 0 No effect; -A small possible conflict; -/-Significant possible conflict; +/Compatibility and conflict elements

\begin{tabular}{|c|c|c|c|c|c|c|c|c|c|c|c|c|c|c|}
\hline \multirow{2}{*}{ SEA objectives } & \multicolumn{14}{|c|}{ The goals of MDP of Ferizaj } \\
\hline & Goal 12 & Goal 13 & Goal 14 & Goal 15 & Goal 16 & Goal & 17 & Goal 18 & Goal 12 & Goal 20 & Goal 21 & Goal 22 & Goal 23 & Goal 24 \\
\hline $\begin{array}{l}\text { Air: Reducing } \\
\text { Greenhouse Gas } \\
\text { Emissions }\end{array}$ & 0 & 0 & 0 & 0 & & & 0 & 0 & + & 0 & 0 & 0 & + & 0 \\
\hline Water quality & + & + & + & + & 0 & & 0 & + & 0 & 0 & 0 & 0 & + & 0 \\
\hline $\begin{array}{l}\text { Land protection } \\
\text { and management }\end{array}$ & 0 & + & 0 & 0 & 0 & & 0 & + & $+i-$ & + & 0 & 0 & 0 & 0 \\
\hline $\begin{array}{l}\text { Biodiversity: } \\
\text { Protection and } \\
\text { managrment. }\end{array}$ & 0 & 0 & 0 & 0 & 0 & & 0 & 0 & 0 & 0 & 0 & 0 & 0 & 0 \\
\hline $\begin{array}{l}\text { Forests: } \\
\text { Sustainable forest }\end{array}$ & 0 & 0 & 0 & 0 & 0 & & 0 & 0 & 0 & 0 & 0 & 0 & 0 & 0 \\
\hline $\begin{array}{l}\text { Landscape and } \\
\text { ecosystem }\end{array}$ & 0 & 0 & 0 & 0 & 0 & & 0 & + & 0 & + & 0 & & 0 & 0 \\
\hline Climate change & $\Pi$ & $\Pi$ & $\Pi$ & $n$ & 0 & & n & 0 & + & 0 & 0 & 0 & + & 0 \\
\hline Cultural heritage & 0 & 0 & 0 & 0 & 0 & & 0 & 0 & 0 & 0 & 0 & 0 & 0 & 0 \\
\hline Quality of life & + & + & + & 0 & + & + & & 0 & 0 & + & + & 0 & + & + \\
\hline
\end{tabular}

Goal 16: Sustainable power supply

Goal 17; Sustainable provision of all Telecommunication services (TEL+DATA+VIDEO) for all citizens, businesses, institutions and households in the Municipality of Ferizaj

. Goal 18; Improving quality in the waste collection service

. Goal 19; Improvement of the road network with accompanying infrastructure in the direction of neighboring municipalities and support of policentric development and facilitation of access to settlements with the establishment of road infrastructure

Goal 20; Creation and improvement of the quality of public spaces in the settlements of Ferizaj (cemeteries, bus stops, parking lots, green areas, rehabilitation of urban and rural commercial spaces) 
Table 5: A summary of the cumulative environmental effects of all elements of the MDP

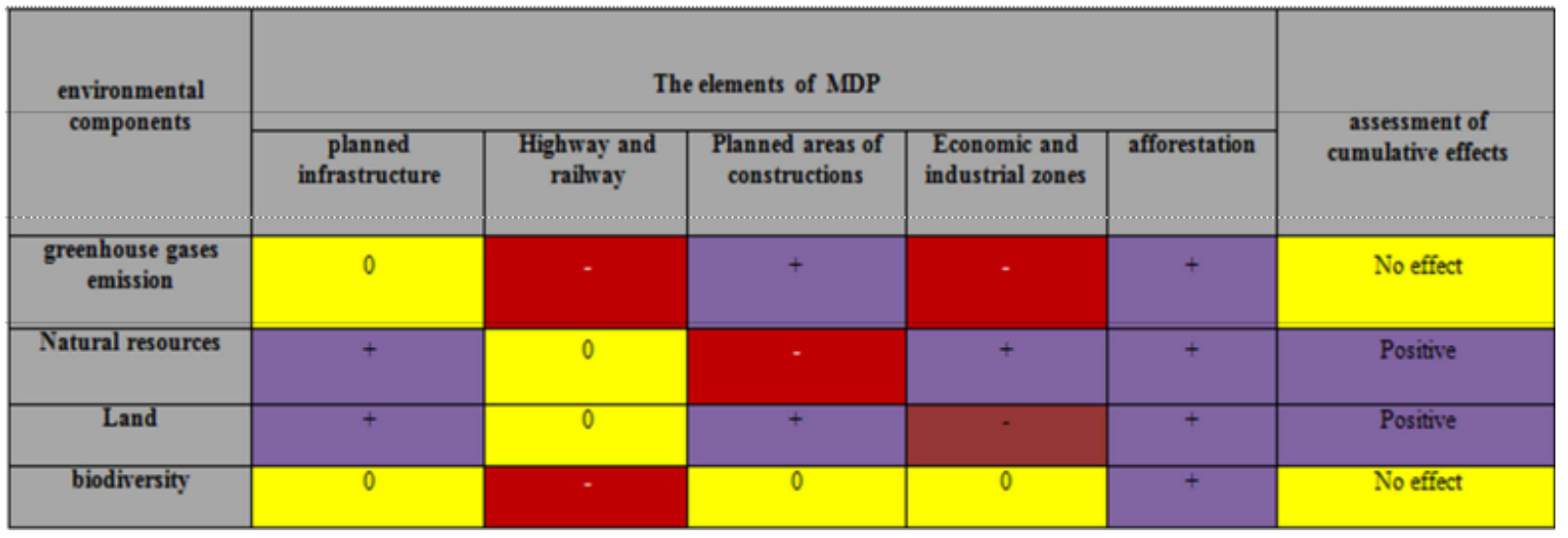

. Goal 21; The lighting infrastructure of settlements in the policentri concept and in general

. Goal 22; Construction of infrastructure for the railway station for loading and unloading with terminal facilities

- Goal 23; Sustainable development of road infrastructure

. Goal 24; Efficient organization of urban transport

\section{Cumulative environmental effects of the the Municipal} Development Plan (MDP) of Ferizaj: The Strategic Environmental Assessment (SEA) should make a general assessment of all activities and policies that are included in the Municipal Development Plan (MDP) of Ferizaj.

From Table 5, the relationship or linkage of environmental components (greenhouse gas emissions, natural resources, land of biodiversity) with elements of MDP (planned roads, highways and railways, planned construction areas, economic and industrial areas and forestation) can be noticed. So, for all the elements of MDP that the users in the environmental components are either positive or have no negative effect

\section{SWOT analysis for environmentally-challenging areas:} The identification of environmental problems such as waste and polluted air is indispensable. With SWOT analysis, the following problems have been addressed: water supply, sewage management, traffic and integrated waste management. The table below shows the advantages and disadvantages according to the SWOT analysis.

\section{Advantages:}

Suitable physico-geographic conditions, developing tourism and sufficient natural resources (Jezerci, Neredimja)

Increasing interest of citizens, state authorities and civil society for the environment
Many problems and environmental challenges have been addressed with the MDP

Good transport conditions for goods and people

Applying financial legal obligations to increase municipal taxes

Qualified teams in implementing the plans and drafting MDP projects

\section{Disadvantages:}

Lack of information for in-depth analysis of planned developments with the MDP

- High level of illegal construction

- Leaving the mountains area to come in the lower areas

Reduction of green spaces and other public spaces

- Not very developed infrastructure (not multifunctional)

Poor waste management

Non-treatment of depleted uranium locations, during the recent war in Kosovo

\section{Opportunities:}

Taking measures for environmental protection

- Donor and government aspirations to address environmental issues

- Development of management and policy capacities at municipal level

- The construction of the wastewater treatment plant in Gerlice and the preliminary treatment of water by the operators

Construction of waste disposal sites

\section{Difficulties:}

Disruption of water and land resources

Disruption of the ecological balance

Degradation of ecosystems, biodiversity, flora and fauna 
Table 6: Summary of environmental problems and MDP response

\begin{tabular}{|c|c|c|c|c|c|}
\hline $\begin{array}{l}\text { Environmental } \\
\text { issue }\end{array}$ & Causes & $\begin{array}{l}\text { The impact on the } \\
\text { environment }\end{array}$ & $\begin{array}{l}\text { The impact on } \\
\text { health }\end{array}$ & MDP proposals & $\begin{array}{l}\text { Other proposed } \\
\text { interventions }\end{array}$ \\
\hline Air quality & $\begin{array}{l}\text { Uncontrolled construction } \\
\text { activity, unpaved roads, } \\
\text { rapid growth of the number } \\
\text { of vehicles, fuel of } \\
\text { poor quality }\end{array}$ & $\begin{array}{l}\text { All the mentioned } \\
\text { causes reduce the air } \\
\text { qualityeven though } \\
\text { this municipality is } \\
\text { heavily covered with } \\
\text { vegetation }\end{array}$ & $\begin{array}{l}\text { There is no evidence } \\
\text { that this connection } \\
\text { is related to illness or } \\
\text { any other illness that } \\
\text { results from air quality }\end{array}$ & $\begin{array}{l}\text { Proposals for afforestation, } \\
\text { public transport proposals } \\
\text { for the purpose of air } \\
\text { pollution reduction in } \\
\text { some municipality areas }\end{array}$ & $\begin{array}{l}\text { To do studies on } \\
\text { afforestation conduct } \\
\text { studies on fuel } \\
\text { transportation (without } \\
\text { sulfur content), } \\
\text { Road improvements in } \\
\text { the municipality }\end{array}$ \\
\hline $\begin{array}{l}\text { The badquality } \\
\text { of river waters }\end{array}$ & $\begin{array}{l}\text { Lack of wastewater and } \\
\text { industrial wastewater } \\
\text { treatment }\end{array}$ & $\begin{array}{l}\text { The impact on the } \\
\text { population's health, } \\
\text { the loss of flora and } \\
\text { fauna, groundwater } \\
\text { contamination }\end{array}$ & $\begin{array}{l}\text { Affects infectious } \\
\text { diseases and other } \\
\text { diseases related to } \\
\text { water and food use }\end{array}$ & $\begin{array}{l}\text { The MDP development } \\
\text { scenario in accordance with } \\
\text { the Kosovo spatial plan } \\
\text { and the location of the site } \\
\text { for the waste water } \\
\text { treatment plant }\end{array}$ & $\begin{array}{l}\text { Preparation of sector } \\
\text { projects for the } \\
\text { treatment of wastewaters } \\
\text { in Ferizaj }\end{array}$ \\
\hline $\begin{array}{l}\text { Lack of } \\
\text { quantitative and } \\
\text { qualitatived } \\
\text { rinking water }\end{array}$ & $\begin{array}{l}\text { Loss in the supply system } \\
\text { and lack of water control }\end{array}$ & $\begin{array}{l}\text { Groundwaters } \\
\text { pollution, water } \\
\text { consumption in } \\
\text { plastic bottles }\end{array}$ & $\begin{array}{l}\text { The spread of } \\
\text { gastrointestinal diseases } \\
\text { but no analysis of the } \\
\text { health effects are } \\
\text { available }\end{array}$ & $\begin{array}{l}\text { The MDP development } \\
\text { scenario in accordance } \\
\text { with the Kosovo } \\
\text { spatial plan }\end{array}$ & $\begin{array}{l}\text { To prepare relevant } \\
\text { sectoral projects } \\
\text { and funding sources }\end{array}$ \\
\hline Waste collection & $\begin{array}{l}\text { Lack of recycle systems } \\
\text { for solid waste. Waste } \\
\text { collection in the } \\
\text { municipality, presence } \\
\text { of illegal landfills } \\
\text { Non-separation of } \\
\text { construction } \\
\text { waste from municipal } \\
\text { waste }\end{array}$ & $\begin{array}{l}\text { The municipality } \\
\text { generates considerable } \\
\text { amounts of solid } \\
\text { waste that pollutes } \\
\text { the river bed, a source } \\
\text { of diseases in the } \\
\text { Summer }\end{array}$ & $\begin{array}{l}\text { Burning waste pollutes } \\
\text { air and endangers health } \\
\text { The potential health } \\
\text { risk comes from the } \\
\text { dumping of hazardous } \\
\text { waste in Ferizaj }\end{array}$ & $\begin{array}{l}\text { The MDP development } \\
\text { scenario in accordance } \\
\text { with the Kosovo spatial } \\
\text { plan, also in accordance } \\
\text { with the site forthe } \\
\text { wastewater treatment plant }\end{array}$ & \\
\hline $\begin{array}{l}\text { Degradation of } \\
\text { forests }\end{array}$ & $\begin{array}{l}\text { Cutting and uncontrolled } \\
\text { burning of forests, } \\
\text { unplanned development } \\
\text { of residences }\end{array}$ & $\begin{array}{l}\text { Air pollution, water } \\
\text { pollution, high level } \\
\text { of erosion and natural } \\
\text { balancing disruption }\end{array}$ & $\begin{array}{l}\text { Water and air pollution } \\
\text { have impact and } \\
\text { consequences on health }\end{array}$ & $\begin{array}{l}\text { Revitalizing existing } \\
\text { for ests, planting new } \\
\text { seedlings and building } \\
\text { parks in some locations }\end{array}$ & \\
\hline $\begin{array}{l}\text { The risk from } \\
\text { earthquakes lands } \\
\text { lides and floods }\end{array}$ & $\begin{array}{l}\text { Ferizaj is located in } \\
\text { a mid-level active } \\
\text { seismic zone, erosion } \\
\text { is present and other } \\
\text { sources of danger as well }\end{array}$ & $\begin{array}{l}\text { It may be of high } \\
\text { environmental impact, } \\
\text { especially by indirect } \\
\text { influences }\end{array}$ & $\begin{array}{l}\text { It can result in } \\
\text { catastrophic } \\
\text { consequences }\end{array}$ & $\begin{array}{l}\text { The MDP does not } \\
\text { represent areas affected } \\
\text { by earthquakes does } \\
\text { not indicate areas } \\
\text { where there is erosion } \\
\text { does not indicate the areas } \\
\text { affected by floods }\end{array}$ & \\
\hline $\begin{array}{l}\text { Risks from } \\
\text { uranium }\end{array}$ & $\begin{array}{l}\text { Throwing shells from } \\
\text { NATO during the war } \\
\text { in Kosovo }\end{array}$ & $\begin{array}{l}\text { It can cause various } \\
\text { health problems }\end{array}$ & $\begin{array}{l}\text { Exposure to } \\
\text { radioactivity } \\
\text { causes cancer }\end{array}$ & $\begin{array}{l}\text { Measures for professional } \\
\text { rehabilitation are foreseen } \\
\text { with MDP }\end{array}$ & \\
\hline $\begin{array}{l}\text { Loss in } \\
\text { biodiversity, loss } \\
\text { of flora and fauna }\end{array}$ & $\begin{array}{l}\text { The growth of some } \\
\text { settlements and } \\
\text { developments in construction } \\
\text { cause forest extinction } \\
\text { andpollution growth }\end{array}$ & $\begin{array}{l}\text { Problems of } \\
\text { ecological losses }\end{array}$ & $\begin{array}{l}\text { Loss of the food chain } \\
\text { Cultural, scientific } \\
\text { and recreational aspects }\end{array}$ & $\begin{array}{l}\text { The definition of } \\
\text { construction is a direct } \\
\text { proposition and the } \\
\text { reduction of improper } \\
\text { development of } \\
\text { settlements leads to } \\
\text { increased biodiversity }\end{array}$ & \\
\hline $\begin{array}{l}\text { Risks from } \\
\text { uranium }\end{array}$ & $\begin{array}{l}\text { Throwing shells from } \\
\text { NATO during the war in } \\
\text { Kosovo }\end{array}$ & $\begin{array}{l}\text { It can cause various } \\
\text { health problems }\end{array}$ & $\begin{array}{l}\text { Exposure to } \\
\text { radioactivity causes } \\
\text { cancer }\end{array}$ & $\begin{array}{l}\text { Measures for professional } \\
\text { rehabilitation are for eseen } \\
\text { with MDP }\end{array}$ & \\
\hline
\end{tabular}

- Endangering the health of the population

- Destruction of cultural and natural heritage

- Property issues conflicts

Environmental problems and solutions given to the MDP intFerizaj: Table 6 presents a brief summary of the environmental problems identified in the above chapter. The proposed solutions of the Municipal Development Plan (MDP) and the suggestions of other measures for environmental protection are given (Anonymous, 2013) (Table 6).

\section{CONCLUSION}

From the analysis of the Municipal Development Plan of Ferizaj, we can clearly tell that the MDP presents a profile with the concept of spatial development, priorities and strategic vision as well as a plan for environmental protection measures. The municipal development plan and the suggestions coming from the strategic environmental assessment will positively influence the revitalization of degraded ecosystems, reforestation and the afforestation 
of some areas that are constantly under the influence of erosion. Moreover, it will also affect the preservation of areas rich in groundwaters and the prohibition of constructions on the river banks. The municipal development plan gives priority to new infrastructure areas (road segments, railways), development of industrial zones, groundwater areas areas with erosion areas for waste disposal, afforestation and reforestation.

The environmental solutions proposed by the MDP are sustainable and in accordance with the current environmental problems in the EU countries. The proposed scenarios from the MDP. For the development of the Municipality of Ferizaj (Scenarios 2 and 4) are realistic and with environmental priorities.

\section{RECOMMENDATIONS}

Some of the recommendations of the strategic environmental assessment are:

- Definition of ecological corridors during road planning and its realization

- Study of biodiversity and natural habitats in the Municipality of Ferizaj

. Drafting of the projects for rehabilitation of areas with potential radiation and depleted uranium treatment after the recent war in Kosovo

. Defining economic, commercial and industrial areas, that are environmentally friendly

- Projects for planning waste management and recycling as well as setting waste collection landfills,

- Definition of groundwater and surface waters areas in accordance with applicable laws
Preservation of natural monuments as well as important natural facilities and defining the location and basic infrastructure for the heating of the city of Ferizaj

\section{REFERENCES}

Anonymous, 2008. Law No.03/L-106 amending law on spatial planning no.2003/14. Republic of Kosovo, Pristina. http://www.gazetazyrtare.com/egov/index.php?option $=$ com_content\&task $=$ view \&i $\mathrm{d}=282 \&$ Itemid $=28 \&$ lang $=$ en

Anonymous, 2011. [Strategic and the action plan for biodiversity 2011-2020]. Republika Kosova-Republic of Kosovo, Pristina, Kosovo. (In Croatian) https://mmph.rks-gov.net/repository/docs/SPVB_ 2011-20_Shqip_899103.pdf

Anonymous, 2013. [Environmental protection strategy (EMS) 2013-2022]. Republika Kosova-Republic of Kosovo, Pristina, Kosovo. (In Croatian) https://mmph.rks-gov.net/repository/docs/Strategjia e_Mbrojtjes_s\%C3\%AB_Mjedisit_-_2013_2022_Shqip_405256.pdf

Anonymous, 2017. Environmental assessments of plans, programmes and projects: Rulings of the court of justice of the European Union. European Union, Brussels, Belgium. http://ec.europa.eu/environment/ eia/pdf/EIA_rulings_web.

Steiner, F.R. and K. Butler, 2012. Planning and Urban Design Standards. American Planning Association, Chicago, Illinois, USA., ISBN-13:978-0-471-47581-1, Pages: 436. 